\title{
Archaeology and the built environment of early medieval England
}

\section{Duncan W. Wright ${ }^{*}$}

John Blair. 2018. Building Anglo-Saxon England. Oxford: Princeton; 978-0-691-16298-0 £49.95.

Pam J. Crabtree. 2018. Early medieval Britain: the rebirth of towns in the post-Roman West. 2018. Cambridge: Cambridge University Press; 978-0521-71370-2 £24.99.

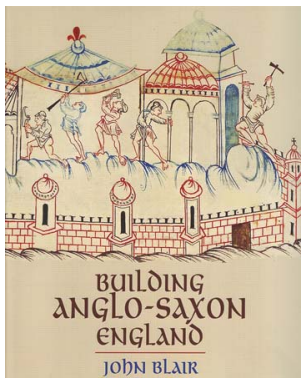

The bulk of people we can now be assured, were content with something that hardly deserves a better title than that of a hovel [...] in such cabins, with bare head room, amid a filthy litter of broken bones, of food and shattered pottery [...] lived the Anglo-Saxons (Leeds 1936: 25-26). This quote from E.T. Leeds, a pioneer of Anglo-Saxon archaeology during the first half of the twentieth century, was inspired by his excavation of settlement remains at Sutton Courtenay, then in Berkshire. Leeds's excavations were actually a breakthrough moment, resulting in the first identification of early medieval settlement structures other than those associated with ecclesiastical sites. In spite of this, the frustration and disappointment with the character and quality of the Sutton Courtenay site are all too apparent in Leeds's assessment. As an expert in Anglo-Saxon artwork, how could he reconcile the skill and craft of fine metalwork, with the ephemeral and impoverished settlement with which he was now dealing? Likewise, where were the great charismatic halls of monumental construction that populated such literary sources as Beowulf? The excavation of the graves of Sutton Hoo, two years after investigations at Sutton Courtney came to a close, served only to amplify the disparity between settlement and burial archaeology_put simply, burials were viewed as richer, grander and far more interesting.
Attitudes did begin to change, albeit subtly, in the post-war period. Brian Hope-Taylor's work at Yeavering showed that early medieval halls could indeed reach grand proportions, and the 1970s witnessed a quantitative revolution in both rural and urban settlement research. Yet the perception that settlement studies represents a poor relation within early medieval archaeology is a reputation that has proved impossible to shake off entirely. One needs just to flick through the review pages of a relevant journal to see that funerary scholarship continues to outstrip research with a settlement focus on a vast scale. There are legitimate reasons for this; there is, for instance, a far more extensive dataset of funerary material, a result of greater academic interest throughout the nineteenth and twentieth centuries. But a more extensive corpus cannot explain entirely the imbalance, and it seems instead that settlements continue to be viewed by many as a complicated, underwhelming and, most worryingly of all, passive product of the early medieval societies that shaped them.

John Blair's Building Anglo-Saxon England is a direct counter to this outlook, putting places of habitation at the forefront of his holistic and compelling study of the built environment. Not only does Blair demonstrate the huge potential of settlement to inform us of changes to the human experience, he also provides a thorough examination of why this archaeology is so frequently difficult to approach. The opening contextual chapters of the volume, for instance, are populated by anthropological comparators for building cultures that will have left little or no trace in the archaeological record. There will always be challenges when arguing from negative evidence, but Blair's parallels are carefully chosen and expertly argued, offering legitimate reasons for the uneven profile of archaeologically identified settlements in early medieval England. A key message here is that lack of permanence does not denote a dearth of sophistication. The emphasis

\footnotetext{
* School of Humanities, Bishop Grosseteste University, Longdales Road, Lincoln LN1 3DY, UK (Email: duncan. wright@bishopg.ac.uk)
} 
from the outset of the volume is on approaching the archaeology from a regional perspective, with particular recognition of the distinctive material culture of the 'eastern zone'-comprising east Yorkshire, the East Midlands and parts of East Anglia. It is from this area that the vast majority of archaeological data derives, but here too that greater continuities in significant places can be traced across the 'Viking Age'.

Chronologically, Blair argues that the evidence is best understood when divided into three; two episodes of transformation in the seventh and tenth centuries, sandwiching a period of consolidation from $c$. AD 720-920. It will come as no surprise that ecclesiastical authorities are viewed as key drivers during both transformative periods; Blair sees the introduction of grid and radial planning during the seventh century, for instance, as deriving from a monastic milieu, while admitting that its use in settlements may be indicative of the pervasive nature of ecclesiastical culture rather than an indicator of church communities per se. The idea that buildings and settlements could have been arranged using systems of perches is to be explored more fully in a future volume (Blair $e t$ al. in press), and is a thesis likely to stimulate much debate among scholars. Irrespective of the interpretation one favours, a significant contribution has already been made in even considering that settlements and other aspects of the built environment could be articulated with such attention and meaning. While issues such as grid planning will no doubt pique particular interest, this should not detract from the monumental scope and depth of Blair's scholarship throughout the entire work. It is hard to overestimate quite how much data have been collected here, not merely from published work and grey literature, but also from myriad conversations with professional and academic archaeologists. The crowning achievement, however, is how this evidence is harnessed into an engaging and accessible narrative, the text delivered throughout with Blair's trademark elegant yet authoritative style.

Some commentators may find discomfort in the allying of the archaeological material so closely with documented individuals and events, but there are aspects to this approach that again are to be welcomed. Especially commendable is the importance placed on pre-Alfredian developments beyond the south of the country, the work successfully breaking free from the triumphant West Saxon narrative that continues to colour so much of our thinking around pre-Conquest England. This is a volume where Mercia is seen as an equal partner in the shaping of Anglo-Saxon England_Offa and Æthelbald in many ways are perceived as the true innovators of cultural and infrastructural contributions that have all too readily been associated with Alfred and his successors. It is difficult to tell whether Building Anglo-Saxon England will have a similar impact to that of Blair's (2005) The church in Anglo-Saxon society, such was the exceptional influence of the earlier work. Yet it may well prove that the ways of thinking forwarded here, especially about settlements and their place in society, represent a watershed moment for Anglo-Saxon scholarship. There has been no greater case for the lingering perception of 'filthy hovels and cabins' to be finally abandoned, and for researchers to engage with settlements with the same thought and meaning as those who originally shaped them.

Pam Crabtree's Early medieval Britain also sets its sights on settlement archaeology, although the greater emphasis here is on tracing the development of urbanism. Despite the title, the volume is almost exclusively concerned with the archaeology of present-day England and the key mechanisms by which towns took shape after the breakdown of Roman authority. The overarching contribution of this work is synthesis and contextualisation, and thus for the most part the work treads familiar territory. The aim of the book, and indeed the series, is to introduce students to early societies that have received sustained archaeological research, and in this Crabtree is successful in producing a highly readable and thorough overview. Crabtree can be particularly commended for not writing a volume too preoccupied with towns alone, but instead interspersed neatly with contextual writing on the evolution and mechanisms for change in settlement throughout the period.

In places the work does come across as somewhat 'traditional' in its execution, however. Deployed here, for example, is the term 'pagan' to describe settlements and other evidence from the earliest medieval centuries, nomenclature that is frankly unhelpful and mercifully decreasingly used in modern scholarship. There is too a disappointing reliance upon documentary narratives and models to provide commentary on the archaeological evidence, while the conventional ethnic dichotomies of Britons and Anglo-Saxons are also sadly adhered to. Some of the reviews of key sites and debates could also have utilised recent contributions more widely, especially those of non-academic fieldwork, as the work of commercial units continues

(C) Antiquity Publications Ltd, 2019 
to outweigh interventions undertaken for research purposes. In spite of these issues, Early medieval Britain provides an ideal orientation to those new to the subject of urbanism, and summarises skilfully the complex data that so typifies early medieval archaeology from towns and their environs. It is a work that will prove useful to scholars too, integrating as it does such a wide range of work into one cohesive and portable text.

\section{References}

BlaIR, J. 2005. The church in Anglo-Saxon society. Oxford: Oxford University Press.

Blair, J., S. Rippon \& C. SMART. In press. Planning in the early medieval landscape. Liverpool: Liverpool University Press.

LeEds, E.T. 1936. Early Anglo-Saxon art and archaeology. Oxford: Clarendon. 